\title{
The Impact of Average Effective Tax Rate on China's Foreign Direct Investment: Evidence from 45 Countries
}

\author{
Yue Wang, Gong Liang Tang \\ The School of Public Finance and Taxation, Central University of Finance and Economics, Beijing, China \\ Email address: \\ 2016110019@email.cufe.edu.cn (Yue Wang),yansuo16@163.com (Gong Liang Tang)
}

\section{To cite this article:}

Yue Wang, Gong Liang Tang. The Impact of Average Effective Tax Rate on China's Foreign Direct Investment: Evidence from 45 Countries. International Journal of Business and Economics Research. Vol. 8, No. 6, 2019, pp. 339-346. doi: 10.11648/j.ijber.20190806.12

Received: July 26, 2019; Accepted: August 20, 2019; Published: September 25, 2019

\begin{abstract}
In the open economy, the government always regards improving the national competitiveness as an important strategic goal. The use of tax means is an important way of the application of national macroeconomic policies. How to effectively improve the competitiveness of the international tax system has become a matter of great concern to us. Based on the OECD average effective tax rate model, this paper uses the average effective tax rate as an indicator of the competitiveness of the international tax system to test its impact on China's FDI decision-making. It is found that the lower average effective tax rate of the host country is beneficial to the inflow of FDI. In the process of calculating the average effective tax rate, enterprise income tax is an important tax parameter affecting the marginal average tax rate. In order to improve the competitiveness of China's tax system, it is suggested to promote foreign investment and attract high-quality foreign direct investment. Consider the perfection of tax system from two perspectives of capital.
\end{abstract}

Keywords: International Tax Competitiveness, OFDI, Average Effective Tax Rate

\section{Introduction}

As from the early 1980 s, the neoliberal tax reform trend has swept across the globe and international tax competition has intensified. The statutory tax rate, progressive grade and tax relief, etc. of corporate income tax and individual income tax have been reduced or decreased. Although some developing countries have increased the efforts in providing tax incentives, the basic trend mentioned above is common in developed and developing countries. In developing countries, the impact of international liberalization has become prominent, the trade tax revenues have declined and the income tax increase pressure have increased. Fierce competition for liquid assets and the cross-border tax avoidance have restricted the taxation of enterprises and high-income earners. The improvement of tax systems of different countries in the world attaches greater importance to marketization, which brings severe challenges to the promotion of equal income distribution and the supply of public goods. The maximum statutory tax rate of individual and enterprise income tax has declined dramatically from the 1980s to today. The global weighted corporate income tax rate dropped from about $46.63 \%$ in 1980 to $26.47 \%$ in
2018 , and the highest rate of personal income tax dropped from $45 \%$ in 1985 to $29 \%$ in 2018 . The reduction of tax rates in developed countries is accompanied by the reduction in the number and scope of various tax relief policies for enterprises and individuals. In developing countries, this trend mainly occurs in middle-income countries, while in low-income countries, increasing tax incentives to attract liquid assets has resulted in a narrowing tax base. Almost every country's income tax progressive grade has been reduced.

The " $13^{\text {th }}$ Five-Year Plan" outline sets out the principle of adhering to the overall coordination of both domestic and international affairs, comprehensively promoting two-way opening and accelerating the cultivation of new advantages in international competition. Under the context of current international economic and political situations, we shall grasp the new connotation of "overall coordination of both domestic and international affairs" in the new era, and understand the new requirements of the new development trend of international taxation on China's tax system. Economists H. B Chenery and A. M. Sturout's famous "Double Gap Model Theory" elaborate on the important role of foreign investment in the economic development of developing countries. How to 
measure the impact of the national tax system on Foreign Direct Investment (FDI) is an important aspect of this paper. Tax jurisdiction is an important part of the country's economic sovereignty, and taxation is an important way for a country's macroeconomic policies to be used independently. As long as the government tries to use taxation to attract more productive factors of production, international tax competition is bound to be a long-standing objective economic phenomenon. The participation of sovereign states in international tax competition is an autonomous act under the market competition. The international tax competition within a certain limit is conducive to the improvement of the welfare level in the participating countries, and has promoted the reform of domestic tax system, allowed the development of modern tax system to show a declined tax rate of liquidity tax source, and thus has a series of positive effects on the economic and social development. These issues are of great significance for the implementation of the national economic development strategy and China's international taxation strategy, and even for the overall planning of the comprehensive deepening reform. How to effectively participate in international tax competition and carry out tax construction has become a matter of great concern to us.

\section{Review of Literature}

As for the quantitative evaluation and measurement of tax competitiveness, the existing methods in the world mainly focus on tax competitiveness and tax neutrality, such as the International Tax Competitiveness Index (ITCI). Referring to the international frontier literature, tax competitiveness is generally measured by the effective tax rate of capital, while tax neutrality (i.e. tax neutrality). The measurement and evaluation of economic distortions are subjective. The forward-looking effective tax rate is divided into the effective marginal tax rate and the average effective tax rate. The average effective tax rate is used to analyze the choice of investment location, while the effective marginal tax rate is used to analyze the impact of tax on investment volume after the selection of investment location. This paper chooses the average effective tax rate to represent the level of international tax competitiveness and makes an empirical analysis of its impact on foreign direct investment. Among the studies on the impact of average effective tax rate on FDI, the most representative ones are King, Fullerton, Devereux, Griffith and OECD. King, Fullerton analyzed the impact of Taxation on capital costs, proposed a method to calculate the forward-looking average effective tax rate, and applied this concept to the comparative analysis of four OECD countries. Devereux, Freeman examined the two-way FDI of the United States from 1984 to 1989 with seven countries, and found that taxation had less impact on FDI from countries with credit system, but had a significant impact on countries with

$$
A^{S L}=\tau \varphi\left[\left(\frac{1}{1+\rho}\right)+\left(\frac{1}{1+\rho}\right)^{2}+\cdots+\left(\frac{1}{1+\rho}\right)^{T}\right]=\frac{\tau \varphi}{\rho}\left(1-(1+\rho)^{-\frac{1}{\varphi}}\right)
$$

Among them, $\rho$ is the discount rate of the final shareholders, $\tau$ is the statutory enterprise income tax rate of the host country, exemption system. Devereux, Griffith studied the impact of tax on marginal investment returns, introduced the concept of average effective tax rate, and discussed the relationship between average effective tax rate, average effective tax rate and statutory tax rate. OECD measured the EMTR and EATRS of international investment in a group of OECD countries between 1991 and 2001. Based on the theoretical model developed by Devereux and Griffith, OECD proposed a new method to calculate the forward-looking effective tax rate (ETRS). Based on the empirical results of OECD in 2016, 36 OECD and partner countries were compared and analyzed. The transnational analysis and application of effective tax rate (EATR) has been mature in the world, but there are few related studies in China. Only a few literatures are based on Devereux, Griffith model or OECD model to calculate the effective tax rate in China. Although some empirical literatures have studied the impact of tax policy on FDI, they have not. Based on the analysis of EATR, there is no empirical study on the impact of EATR on China's OFDI. Based on the latest theoretical model of EATR measurement developed by OECD, this paper makes an empirical analysis of the impact of transnational EATR level on China's OFDI and puts forward policy recommendations to improve China's tax competitiveness. Therefore, on the one hand, this paper has important practical value, on the other hand, it also has a certain degree of tribute to the existing theoretical research. Dedication.

\section{Methodology}

The average effective tax rate model of OECD is based on the theoretical model developed by Devereux and Griffith, which is used to evaluate how tax affects the motivation of expanding investment. The Oxford National Centre for Business Taxation (CBT) and the European Economic Research Centre (ZEW) have published ETRS that can be compared at the national level. At present, the calculation only includes corporate tax, considering three types of general assets: construction, machinery, intangible assets and inventory. In terms of depreciation method, linear depreciation and declining balance depreciation and their combination are considered.

Assume an investment path: foreign investors invest in parent companies of foreign countries in the form of equity or bonds. Subsidiaries only rely on issuing new shares to the parent company to finance. The parent company only invests in domestic subsidiaries through FDI channels through retained earnings financing. The tax exemption law is adopted for income from foreign sources in residential countries.

If the company invests in fixed assets, under the premise of Linear Depreciation Method (SL), the present value $A^{S L}$ of fixed assets can be expressed as: $\varphi$ is the depreciation rate of fixed assets, and $T$ is the depreciation period of fixed assets. 
Enterprises need to satisfy the following equilibrium conditions at time t:

$$
\left(1+\left(1-\mathrm{m}^{i}\right) \mathrm{i}\right) \mathrm{V}_{t}=\frac{\left(1-m^{d}\right)\left(1-w^{d}\right)}{1-c} D_{t}-N_{t}+V_{t+1}-z\left(V_{t+1}-V_{t}-N_{t}\right)
$$

Because enterprise value can be expressed as:

$$
\mathrm{V}_{t}=\frac{\gamma D_{t}-N_{t}+V_{t+1}}{1+\rho}
$$

Where $\rho=\frac{\left(1-\mathrm{m}^{i}\right) \mathrm{i}}{1-z}$ and $\gamma=\frac{\left(1-m^{d}\right)\left(1-w^{d}\right)}{(1-z)(1-c)}$.

If the subsidiary company chooses equity financing and the parent company chooses retained earnings financing, the economic rent equals the change of enterprise value in a given time.

$$
\mathrm{R}^{R E}=-\gamma(1-A)+\frac{\gamma}{1+\rho}[(p+\delta)(1+\pi)(1-\tau)+(1-\delta)(1+\pi)(1-A)]
$$

In general, external financing costs are summarized as follows.

$$
\begin{gathered}
\mathrm{F}=\gamma \mathrm{dB}_{t}\left[1-\frac{1+i(1-\tau)}{1+\rho}\right]-(1-\gamma) \mathrm{d} N_{t}\left[1-\frac{1}{1+\rho}\right] \\
\mathrm{R}=\mathrm{R}^{R E}+F
\end{gathered}
$$

All three cases can be summarised by equation as follows.

$$
\begin{aligned}
& \mathrm{F}=\left\{\begin{array}{c}
0 \text { Retailed Earnings } \\
F^{N E} \text { New Equity } \\
F^{D E} \text { Debt }
\end{array}\right. \\
& \text { EATR }=\frac{\left(\frac{p-r}{1-r}\right)}{\left(\frac{p}{1+r}\right)}-\frac{(1-z)\left\{\frac{\gamma}{1-\rho}[(p+\delta)(1+\pi)(1-\tau)-((1+\rho)-(1-\delta)(1+\pi))(1-A)]+F\right\}}{\left(\frac{p}{1+r}\right)}
\end{aligned}
$$

\section{Empirical Analysis: The Impact of Average Effective Tax Rate of Capital on China's Foreign Direct Investment}

\subsection{Data, Variables and Model}

\subsubsection{Variable Selection}

Explaned variables: Because of the unstable characteristics of China's outward investment flows, there are many negative or zero values of investment flows to some countries, which can not be logarized to reduce heteroscedasticity to meet the

$$
\begin{gathered}
F^{N E}=\frac{-\rho(1-\gamma)}{1+\rho} \\
F^{D E}=\frac{\gamma}{1+\rho}(\rho-i(1-\tau))
\end{gathered}
$$

\begin{tabular}{|c|c|c|}
\hline Explanatory variables (logarithmic) & data sources & Brief description \\
\hline EATR & CET、ZEW Database & $\begin{array}{l}\text { This variable is calculated according to the OECD (2018) forward-looking effective tax } \\
\text { rate calculation model. }\end{array}$ \\
\hline Economic freedom & World Bank Database & This variable controls the quality of institutional factors in the host country. \\
\hline Natural resource reserve & World Bank Database & This variable represents the abundance of natural resources in the host country. \\
\hline GDP & World Bank Database & $\begin{array}{l}\text { This variable represents the controlling variable of economic scale, including GDP of } \\
45 \text { host countries in } 2005-2016 \text {. }\end{array}$ \\
\hline Per capita GDP & World Bank Database & $\begin{array}{l}\text { This variable is equal to GDP divided by the number of people in the middle of the year, } \\
\text { reflecting the degree of prosperity of the host country. }\end{array}$ \\
\hline Distance cost & CEP II Database & $\begin{array}{l}\text { This variable represents the geographical distance between China and the target country } \\
\text { multiplied by the international weighted average oil price. }\end{array}$ \\
\hline Market Openness & World Bank Database & This variable equals the total trade of 45 host countries divided by GDP. \\
\hline Total labour force & World Bank Database & This variable represents the abundance of labor resources in the host country. \\
\hline
\end{tabular}

Setting all taxes to zero then yields the corresponding rent in the absence of tax: $\mathrm{R}^{*}=(p-r) /(1-r)$. Substituting $\mathrm{R}^{*}$ and $\mathrm{R}$ into the definition yields a general expression for the EATR which will be used in the model

Table 1. Variables and data sources. 


\subsubsection{Model Establishment and Data Sources}

From the location distribution of China's FDI, due to the availability of data, after excluding the host countries with missing data, the research sample covers 45 countries of OECD and G20, including major developed and developing economies in the world. The research period is from 2005 to 2016 .

In order to study the impact of the international tax competitiveness represented by the average effective tax rate (EATR) on FDI, based on the classical gravity model, this paper introduces the variables of average effective tax rate, economic development level, investment demand, market openness, system quality, resource endowment and labor scale. For explaining variables. Because the investment cycle has long-term characteristics, the lagging one-stage variable $\mathrm{OFDI}_{i t-1}$ is also introduced into the explanatory variables. In this paper, all non-proportional data are logarized to reduce heteroscedasticity. The dynamic panel regression model is constructed as follows:

$$
\begin{gathered}
\operatorname{InOFDI}_{i t}=\beta_{0}+\beta_{1} \operatorname{lnOFDI}_{i t-1}+\beta_{2} \ln G D P P_{i t}+\beta_{3} \ln G D P_{i t}+\beta_{4} \ln O P E N_{i t}+\beta_{5} \ln L A B O U R_{i t}+\beta_{6} \ln D I S_{i t}+\beta_{7} N R_{i t} \\
+\beta_{8} P S_{i t}+\beta_{9} E A T R_{i t}+\gamma_{i}+\mu_{i}+\varepsilon_{i t}
\end{gathered}
$$

Where $\mathrm{i}$ is $\mu_{i}$ for the national effect, $\gamma_{i}$ for the time effect, and $\varepsilon_{i t}$ for the random disturbance term.

\subsection{Analysis of Empirical Results}

\subsubsection{Correlation Test, Stationarity Test and Granger Causality Test}

After the correlation test, by observing the Spearman correlation coefficient and the Pearson correlation coefficient in the correlation analysis matrix, there is a strong correlation between $\operatorname{lnOFDI}$ and $\operatorname{lnGDP}$. In addition, lnLABOUR also has strong correlation. There is a weak correlation between the remaining variables and lnOFDI. In this paper, LLC, IPS, ADF-Fisher and PP-Fisher tests are used for stationarity test. The LLC test is stable with the same root, and the other three tests are heterogeneous. The null hypothesis of all tests in the table is: unit root process, non-stationary. The $\mathrm{P}$ value is less than a given significant level of 0.05 , so the null hypothesis is rejected and the sequence is considered to be stationary. The ADF statistic of the Kao test is -4.853 , and the corresponding $\mathrm{P}$ value is less than 0.05 , and the null hypothesis is rejected. Therefore, there is a cointegration relationship among the variables, indicating that there is a long-term equilibrium. After the Granger causality test, the variables have statistical causes and effects. Comparing the relationship between $\mathrm{P}$ value and 0.05 , it can be seen that when lnOFDI is used as the explanatory variable, there are independent variables to explain its change. Therefore, this paper can use lnOFDI as the explanatory variable to establish a dynamic panel regression model.

\subsubsection{Estimated Results}

This paper applies stata based on the system GMM model to examine the 2005-2016 panel data of 45 member countries of OECD and G20. Table 2 shows the results of the model regression analysis. The $\mathrm{P}$ values of $\mathrm{AR}(2)$ are all greater than 0.05 , indicating that there is no second-order autocorrelation. Through the Hansen test, the tool variables are not over-recognized, indicating that the tool variables are valid, so there is no disturbance item autocorrelation problem, and all instrument variables are valid, and GMM estimation can be performed. Before the introduction of the average effective tax rate, the results of model (1) in Table 2 show that the regression coefficients of the host country's economic development level, host country market openness, labor size, distance cost, resource endowment, and institutional quality all meet at least 5\% significant. Sex level test. Model (1) shows that for every $1 \%$ increase in per capita GDP of the host country, foreign direct investment will increase by $1.922 \%$, which confirms the previous literature that China's foreign direct investment tends to flow to higher economies with higher economic development levels. The regression coefficient of the potential market size characterized by gross domestic product is -0.932 , and the openness of the host country market is positively correlated with the level of foreign direct investment, with a regression coefficient of 0.94 . The regression coefficient for geographic distance cost is 0.339 . Natural resources and labor are positively correlated with the level of foreign direct investment. The regression coefficients are 0.215 and 1.661 respectively, indicating that the resource endowment and labor level of the host country are more attractive to FDI from China than the potential market demand. The distance cost is negatively correlated with OFDI, and the regression coefficient is -0.339 , which confirms the existing literature on China's foreign direct investment relatively preferring neighboring countries.

Model (2) is the regression result after introducing the average effective tax rate (EATR) that characterizes the international tax competitiveness level. The regression coefficient of the average effective tax rate (EATR) is -13.206 , and satisfies the significance test at the $1 \%$ level. The average effective tax rate (EATR) is negatively related to China's foreign direct investment level. The lower the average effective tax rate (EATR), the stronger the corresponding international tax competitiveness, the higher the level of China's foreign direct investment. After the introduction of the average effective tax rate (EATR), the level of economic development, institutional factors of the host country, and the degree of influence of the natural resource factors of the host country on the level of China's foreign investment have been reduced to some extent, so the national taxation competitiveness of the average effective tax rate (EATR) The level has a certain degree of weakening effect on the level of economic development, the institutional factors of the host country, and the influence of the natural resource factors of the host country on FDI. 
Table 2. Estimation results.

\begin{tabular}{|c|c|c|}
\hline & (1) & (2) \\
\hline & InOFDI & InOFDI \\
\hline L. InOFDI & $0.655 * * *$ & $0.572 * * *$ \\
\hline & & \\
\hline $\operatorname{lnGDPP}$ & $\begin{array}{l}1.922 * * * \\
(0.716)\end{array}$ & $\begin{array}{l}1.310^{*} \\
(0.692)\end{array}$ \\
\hline $\operatorname{lnGDP}$ & $\begin{array}{l}-0.932 \\
(0.689)\end{array}$ & $\begin{array}{l}0.633 \\
(0.771)\end{array}$ \\
\hline lnOPEN & $\begin{array}{l}0.940^{* * *} \\
(0.104)\end{array}$ & $\begin{array}{l}-0.588^{* * *} \\
(0.204)\end{array}$ \\
\hline lnLABOUR & $\begin{array}{l}1.661^{* *} \\
(0.715)\end{array}$ & $\begin{array}{l}-0.038 \\
(0.795)\end{array}$ \\
\hline $\operatorname{lnDIS}$ & $\begin{array}{l}-0.339 * * * \\
(0.038)\end{array}$ & $\begin{array}{l}-0.300^{* * * *} \\
(0.084)\end{array}$ \\
\hline $\operatorname{lnNR}$ & $\begin{array}{l}0.215^{* * *} \\
(0.049)\end{array}$ & $\begin{array}{l}0.160 * \\
(0.092)\end{array}$ \\
\hline $\operatorname{lnPS}$ & $\begin{array}{l}-3.383^{* * *} \\
(0.293)\end{array}$ & $\begin{array}{l}-1.256^{* *} \\
(0.561)\end{array}$ \\
\hline EATR & & $\begin{array}{l}-13.206 * * * \\
(1.108)\end{array}$ \\
\hline _cons & $\begin{array}{l}-3.118^{*} \\
(1.701)\end{array}$ & $\begin{array}{l}-9.237 * * \\
(4.473)\end{array}$ \\
\hline AR (1)-P & $-2.00(0.045)$ & $-1.99(0.046)$ \\
\hline AR (2)-P & $0.52(0.605)$ & $0.56(0.573)$ \\
\hline Hansen & $40.79(0.908)$ & $41.66(0.870)$ \\
\hline $\mathrm{N}$ & 484 & 484 \\
\hline
\end{tabular}

\subsection{Robustness Checks}

In this paper, the system GMM estimation method is mainly used. When the robustness test is carried out, the difference GMM is used to estimate the parameters of the regression model, and the results of the two are compared. In addition, the EATR is replaced by EMTR (marginal average effective tax rate). It can be found that after the introduction of the variable EMTR, the coefficient symbol of each variable does not change, and the change of the coefficient value becomes more stable, and the standard error has no obvious change. Therefore, the regression coefficient can be considered as the method of different parameter estimation. It is steady.

Table 3. Robustness.

\begin{tabular}{|c|c|c|c|c|}
\hline & (1) & (2) & (3) & (4) \\
\hline & System GMM & Differential GMM & System GMM & Differential GMM \\
\hline \multirow{2}{*}{ L. $\operatorname{lnOFDI}$} & $0.655^{* * *}$ & $0.645 * * *$ & $0.572 * * *$ & $0.600 * * *$ \\
\hline & $(0.008)$ & $(0.007)$ & $(0.011)$ & $(0.005)$ \\
\hline \multirow{2}{*}{$\operatorname{lnGDPP}$} & $1.922 * * *$ & $3.568 * * *$ & $1.310^{*}$ & 1.416 \\
\hline & $(0.716)$ & $(0.837)$ & $(0.692)$ & $(0.946)$ \\
\hline \multirow{2}{*}{$\operatorname{lnGDP}$} & -0.932 & $-2.470 * * *$ & 0.633 & 0.099 \\
\hline & $(0.689)$ & $(0.788)$ & $(0.771)$ & $(0.927)$ \\
\hline \multirow{2}{*}{ InOPEN } & $0.940 * * *$ & $0.959 * * *$ & $-0.588^{* * *}$ & $-0.555^{* * *}$ \\
\hline & $(0.104)$ & (0.099) & $(0.204)$ & $(0.153)$ \\
\hline \multirow{2}{*}{ InLABOUR } & $1.661^{* *}$ & $3.289 * * *$ & -0.038 & 0.420 \\
\hline & $(0.715)$ & $(0.800)$ & $(0.795)$ & $(0.948)$ \\
\hline \multirow{2}{*}{$\operatorname{lnDIS}$} & $-0.339 * * *$ & $-0.325^{* * *}$ & $-0.300 * * *$ & $-0.335^{* * *}$ \\
\hline & $(0.038)$ & $(0.023)$ & $(0.084)$ & $(0.058)$ \\
\hline \multirow{2}{*}{$\operatorname{lnNR}$} & $0.215^{* * *}$ & $0.153 * * *$ & $0.160^{*}$ & $0.153^{* *}$ \\
\hline & $(0.049)$ & $(0.037)$ & $(0.092)$ & $(0.068)$ \\
\hline \multirow{2}{*}{$\ln P S$} & $-3.383 * * *$ & $-4.246 * * *$ & $-1.256 * *$ & $-1.140 *$ \\
\hline & $(0.293)$ & $(0.649)$ & $(0.561)$ & $(0.631)$ \\
\hline \multirow{2}{*}{ eatr } & & & $-1.206^{* * *}$ & $-9.997 * * *$ \\
\hline & & & $(1.108)$ & $(0.809)$ \\
\hline \multirow{2}{*}{ _cons } & $-3.118^{*}$ & -0.889 & $-9.237 * *$ & -5.801 \\
\hline & $(1.701)$ & $(2.710)$ & $(4.473)$ & (3.917) \\
\hline AR (1)-P & $-2.00(0.045)$ & $-1.98(0.048)$ & $-1.99(0.046)$ & $-1.98(0.048)$ \\
\hline AR (2)-P & $0.52(0.605)$ & $0.52(0.600)$ & $0.56(0.573)$ & $0.52(0.600)$ \\
\hline Hansen & $40.79(0.908)$ & $40.92(0.905)$ & $41.66(0.870)$ & $40.92(0.905)$ \\
\hline $\mathrm{N}$ & 484 & 484 & 484 & 484 \\
\hline
\end{tabular}


Table 4. Robustness for substitution variables.

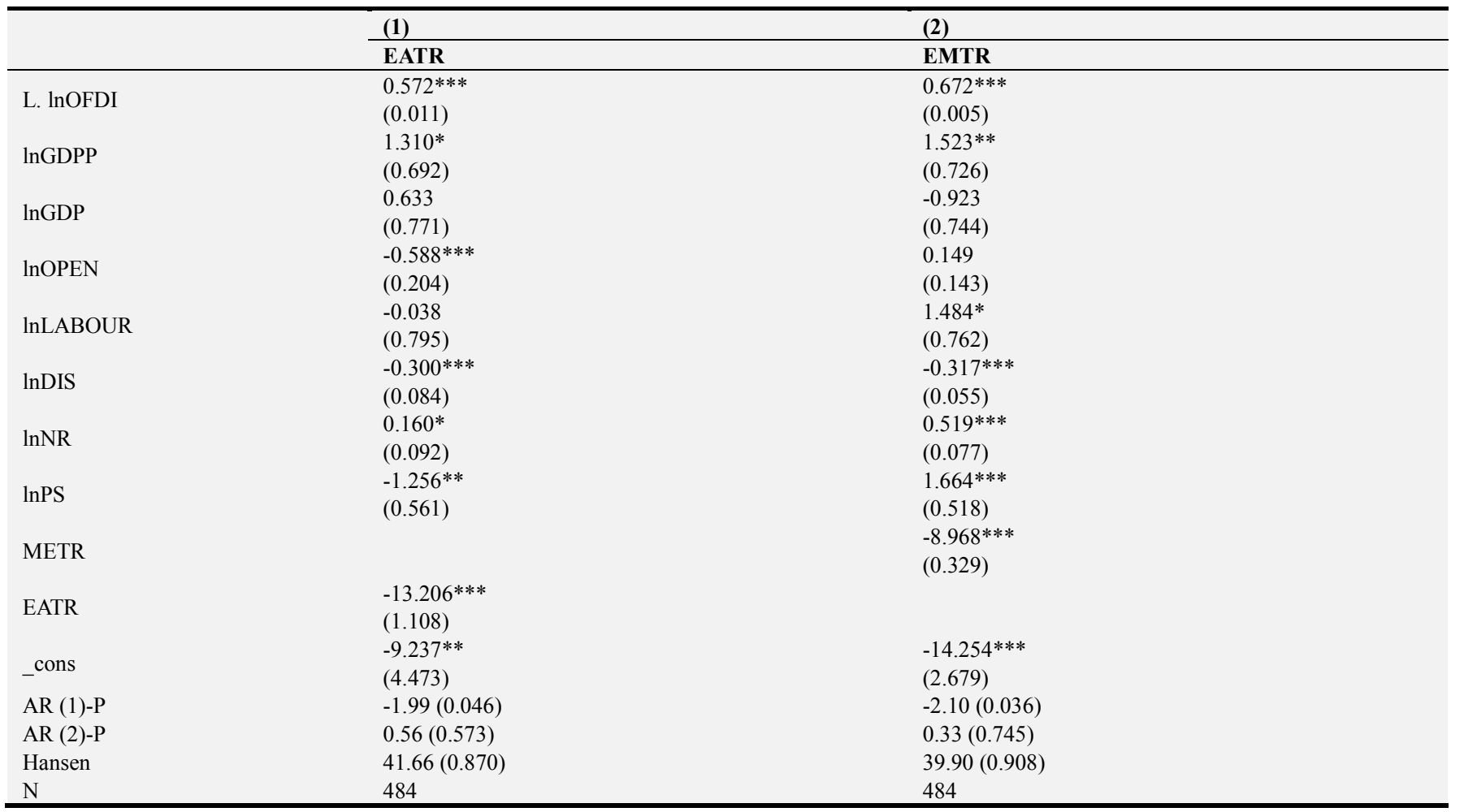

\section{Findings}

In this paper, based on the OECD effective average tax rate model (2018), the cross-country comparable data has been calculated and used as an index of international tax system competitiveness. Its impact on China's foreign direct investment choices has been tested by constructing an investment expansion gravity model. The main research conclusions and the specific policy recommendations provided herein are as follows:

Firstly, the host country's economic development level, market size, natural resource abundance, labor abundance, distance cost and effective average tax rate (EATR) have a significant impact on China's foreign direct investment. The level of economic development, the abundance of natural resources and the number of labor force have positive effects, while the average effective tax rate, market size and distance cost have negative effects. The lower the average effective tax rate (EATR), the stronger the international tax competitiveness, the higher the level of direct investment in China. Average Effective Tax Rate (EATR) is negatively correlated with China's level of foreign direct investment. The reduction of the average Effective Tax Rate in the host country is conducive to China's FDI inflow, which is consistent with the theoretical analysis of international tax competition and the characteristics of the current situation of international tax competition.

Secondly, under the influence of national tax competitiveness characterized by the effective average tax rate, more China's foreign direct investments flow to countries with lower economic development level, natural resource abundance and economic freedom. After introducing the average effective tax rate (EATR), the level of economic development, the institutional factors of the host country and the natural resources factors of the host country have a certain degree of reduction in the impact on the level of China's foreign investment. Therefore, the level of national tax competitiveness represented by the average effective tax rate (EATR) on the level of economic development and the system of the host country. Factor, natural resource factor of host country has a certain degree of weakening effect on FDI. The conclusions of this study have important policy implications. In order to promote China's tax competitiveness, it is necessary to consider the improvement of tax policy from two aspects: promoting foreign investment and attracting high-quality foreign direct investment.

\section{Conclusions}

On the one hand, we shall improve the current taxation system of China from the perspective of promoting foreign investment. Specifically, we can consider from the perspectives of the corporate income tax system and the export tax rebate system. The credit for overseas income in the corporate income tax is not thorough. The overseas tax credit law has certain defects, which make it conducive to promoting foreign investment. First, if the tax rate of the host country is low, the foreign investment income shall be subject to supplementary taxation according to China's tax rate, so it cannot be motivated by the low overseas tax rate. Secondly, the deduction has both the requirement of holding proportion 
and the hierarchical regulation: the taxation of resident enterprises directly and indirectly controlling $20 \%$ or more of overseas enterprises can be deducted; even if document 84 stipulates that the deduction of holding proportion should be adjusted from three levels to five levels, the implementation of the comprehensive quota deduction law and the increase of the deduction level of overseas enterprises cannot be solved. The problem that enterprises still have to pay taxes to invest in low-tax countries should be solved.

In 2017, the weighted average value of corporate income tax in the world is $22.96 \%$, while the current statutory tax rate of corporate income tax in China is $25 \%$. Therefore, it is necessary to reduce the nominal tax rate of corporate income tax. The solution may be to reduce the enterprise income tax rate of our country to about $20 \%$, at which time the host country's tax rate is higher than that of our country in most cases, and exempt tax law should be implemented at the same time. This will not only attract multinational companies to invest in factories, or even set up headquarters, but also will not have a greater impact on financial revenue. In addition, the current procedures for adjusting costs and expenses of foreign-invested enterprises are rather cumbersome and should be simplified. It is suggested that enterprises should be allowed to withdraw risk reserve for overseas investment before tax, so as to enhance the risk prevention and control of enterprises.

In addition, we shall also take into account the improvement of tax incentives. Specifically, it is recommended to allow the domestic and foreign covering of operating losses or to the extension of the carry-over period; to establish a system of accelerated depreciation; to establish an overseas investment risk reserve system; and to establish a delayed taxation system. It is suggested that the zero tax rate policy be adopted for the export of multinational enterprises in order to promote the export of products and services by "going out" enterprises. Specific measures are proposed to clarify the tax rebate problems of some "going out" modes, increase the tax rebate intensity; increase the tax rebate intensity of large sets of forming equipment parts to encourage the development of large-scale overseas contracted projects; allow the export of service industry to implement the tax rebate policy, so as to promote the external development of service industry in China.

On the other hand, in order to attract high-quality foreign direct investment, consideration can be made from the levels of general policy and special policy. With regard to the general policy, first is to improve the tax incentives for high-tech: appropriately shorten the depreciation period of intangible assets, increase the carry-over period for deduction of technology development fees, and improve the efforts in the accelerated depreciation of high-tech equipment. Secondly, it is suggested to improve the tax incentive system for investment in infrastructure, accelerate depreciation and give preferential policies for reinvestment tax rebate in order to reduce investment costs and risks. Thirdly, we should improve the tax incentive system of energy-saving and environmental protection industries, such as accelerating depreciation, investment credits and so on, so as to reduce production costs and improve investment returns. In respect of special policy, in order to improve the quality of China's opening to the outside world, the development of the headquarters economy may be taken an important policy goal. More tax incentives may be given than those offered by neighboring countries. With regard to preferential methods, there shall be direct preferential treatments such as preferential tax rate, tax amount reduction or relief and preferential period, etc., as well as indirect preferential methods, such as accelerated depreciation, pre-tax deduction and loss deduction, etc. In this way, we can form a policy system featured by international tax competitiveness that allows us to attract high-quality investments and promote foreign investment.

\section{References}

[1] Bird R M. Taxation and development: what have we learned from fifty years of research [Z]. International Center for Tax and Development, Working Paper, 2012. Tax and Development, Working Paper, 2012.

[2] Kumar M S, Quinn D P. Globalization and corporate taxation [Z]. International Monetary Fund, Working Paper, 2012.

[3] Aizenman J, Jinjarek Y. Globalization and developing countries - a shrinking tax base? [J]. Journal of Development Studies, 2009, 45 (5): 653-71.

[4] Keen M, Konrad K A. International tax competition and coordination [Z]. Max Planck Institute for Tax Law and Public Finance, Working Paper, 2012, 257-328.

[5] Ganghof S. Adjusting national tax policy to economic internationalization: strategies and outcomes [M]. Oxford: Oxford University Press, 2000, 597-645.

[6] Swank D, Steinmo S. The new political economy of taxation in advanced capitalist democracies [J]. American Journal of Political Science, 2002, 46 (3): 642-55.

[7] Keen M, Simone A. Is tax competition harming developing countries more than developed? [J]. Tax Notes International, 2004, 34 (13): 1317-26.

[8] Peter K S, Buttrick S, Duncan D. Global reform of personal income taxation 1981-2005: evidence from 189 countries [J]. National Tax Journal, 2010, 63 (3): 447-478.

[9] King M A, Fullerton D. The taxation of income from capital: a comparisons of effective tax rates [R]. 1983, 278 (2): 121-136.

[10] Devereux M P, Griffith R. Evaluating Tax Policy for Location Decisions [J]. International Tax and Public Finance, 2003, (10): $107-126$.

[11] Devereux M P, Freeman H. The Impact of Tax on Foreign Direct Investment: Empirical Evidence and the Implications for Tax Integration Schemes [J]. International Tax and Public Finance, 1995, 2 (1): 85-106.

[12] Hanappi T. Corporate Effective Tax Rates-Model Description and Results From 36 OECD and Non-OECD Countries [R]. Paris: OECD, 2018, 7. 
[13] Oxford University Centre for Business Taxation. Business Taxation under the Coalition Government [R]. Oxford: Oxford University Centre For Business Taxation, 2015, 5.

[14] Matthews S. What is a "Competitive" Tax System? [R]. Paris: OECD, 2011, 7.
[15] Egger P, Raff $\mathrm{H}$. Tax rate and tax base competition for foreign direct investment [J]. International Tax Public Finance, 2014, 22 (5): $777-810$.

[16] Tax Foundation. International Tax Competitiveness Index 2018 [R]. Washington, DC: Tax Foundation, 2018, 10. 